\title{
PENGELOLAAN EKSPRESI BUDAYA TRADISIONAL (EBT) DI DAERAH PASCA UNDANG-UNDANG NOMOR 28 TAHUN 2014 TENTANG HAK CIPTA (PERPEKTIF HUKUM ADMINISTRASI NEGARA)
}

\author{
Oleh: \\ Sigit Nugroho, SH., MH. \\ Dosen FH UBB \\ Email: snugroho571@gmail.com
}

\begin{abstract}
The Traditional Culture Expression reflects cultural identity. It also shows district's culture character and style. The local's historical value, character and identity are implemented so Indonesia is rich of culture. The Traditional Culture Expression is as one of the intelectual property or treasure which is public charactereristic has economic rights for its society. The Traditional Culture Expression must be utilized and developed efficiently and effectively by its society as its users and owners unless it will reduce the economic rights of the society as its owner. The Traditional Culture Expression needs to protect to avoid the abuse and legal action. Therefore it is necessary to provide an adequate regultion and management for the Traditional Culture Expression.The management of Traditional Culture Expression done by government must pay attention on good governence principles and ccoperate with stakeholders and the Intelectual Property Center in distric area or province. The management of Traditional Culture Expression is applied by inventoring and protecting it based on the valid regulation to register it at authorized government agency.
\end{abstract}

Keyword: Management, Traditional Culture Expression, the district area

\begin{abstract}
Abstrak
Ekspresi budaya tradisional menunjukkan identitas kultural. Ekspresi budaya tradisional menampilkan watak dan corak kebudayaan daerah. Historisitas daerah itu dimanivestasikan dan dengan demikian sekaligus juga karekter atau identitas, sehingga bangsa Indonesia kaya akan budaya. Ekspresi budaya tradisional yang merupakan salah satu kekayaan intelektual yang bersifat komunal memiliki hak ekonomi. Ekspresi budaya tradisional bila digunakan oleh pihak yang tidak bertanggung jawab dapat merugikan atau mengurangi hak ekonomi masyarakat pengembannya. Selain itu bila tidak dilindungi maka akan dapat disalahgunakan dan juga berpotensi terjadi sengketa. Untuk itu perlu adanya peraturan perundang-undangan yang memadai dan perlunya pengelolaan yang baik terhadap ekspresi budaya tradisional. Pengelolaan ekspresi budaya tradisional yang dilakukan pemerintah harus memperhatikan asas-asas pemerintahan yang baik dan harus bekerjasama dengan stakeholder dan Sentra Kekayaan Intelektual yang ada di daerah. Pengelolaan ekspresi budaya tradisional dilakukan dengan menginventarisasi dan melindunginya sesuai dengan peraturan perundang-undangan yang berlaku saat ini yakni dengan mendaftarkannya di instansi pemerintah yang berwenang.
\end{abstract}

Kata kunci: pengelolaan, ekspresi budaya tradisional, daerah 


\section{A. PENDAHULUAN}

Bangsa Indonesia merupakan negara yang kaya akan budaya. Terdapat lebih dari 300 kelompok etnik atau suku bangsa di Indonesia. atau tepatnya 1.340 suku bangsa menurut sensus BPS tahun 2010. ${ }^{1}$ Suku Jawa adalah kelompok suku terbesar di Indonesia dengan jumlah mencapai $41 \%$ dari total populasi. Orang Jawa kebanyakan berkumpul di pulau Jawa, akan tetapi jutaan jiwa telah bertransmigrasi dan tersebar ke berbagai pulau di Nusantara ${ }^{2}$ bahkan bermigrasi ke luar negeri seperti ke Malaysia dan

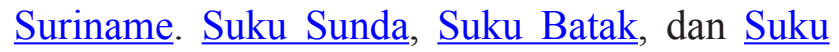
Madura adalah kelompok terbesar berikutnya di negara ini. Banyak suku-suku terpencil, terutama di Kalimantan dan Papua, memiliki populasi kecil yang hanya beranggotakan ratusan orang. Sebagian besar bahasa daerah masuk dalam golongan rumpun bahasa Austronesia, meskipun demikian sejumlah besar suku di Papua tergolong dalam rumpun bahasa Papua atau Melanesia. ${ }^{3}$

Banyaknya suku bangsa yang ada di Indonesia membuktikan pula banyaknya budaya yang dimilikinya. Budaya yang dimiliki oleh masyarakat baik benda maupun tak benda merupakan karya cipta masyarakat bangsa Indonesia yang perlu adanya perlindungan. Perlindungan dalam hal ini mencakup pengembangan, pemanfaatan, pelestarian, penjagaan dan pemeliharaan yang harus ada campur tangan dari pemerintah dan masyarakat secara sinergis. Segala bentuk ekspresi, baik material (benda) maupun immaterial (tak benda), atau kombinasi keduanya yang dihasilkan oleh masyarakat di Indonesia harus dilindungi dengan pengelolaan yang baik.

Manajemen perlindungan ekspresi budaya tradisional yang baik perlu dilakukan karena banyak sekali beberapa waktu yang lalu adanya

1 Suku Bangsa di Indonesia, https://id.wikipedia.org/ wiki/Suku bangsa di Indonesia\#Referensi, diakses tanggal 26 Mei 2017, pukul 08.30 WIB.

2 Indonesia's Population: Ethnicity and Religion in a Changing Political Landscape. Institute of Southeast Asian Studies. 2003 dalam Suku Bangsa di Indonesia, https://id.wikipedia.org/wiki/Suku bangsa_di Indonesia\#Referensi, diakses tanggal 26 Mei 2017, pukul 08.30 WIB.

3 Ibid. penggunaan ekspresi budaya tradisional Indonesia yang sembarangan digunakan oleh pihak lain atau bukan masyarakat pengembannya. Bila penggunaan tersebut untuk komersial oleh pihak yang tidak bertanggung jawab maka akan sangat merugikan bangsa Indonesia terutama masyarakat pengembannya. Undang-Undang Dasar Negara Republik Indonesiatelah menjamin penghormatan terhadap kesatuan-kesatuan masyarakat hukum adat beserta hak-hak tradisionalnya sepanjang masih hidup dan sesuai dengan perkembangan masyarakat dan prinsip Negara Kesatuan Republik Indonesia. ${ }^{4}$ Konstitusi sudah jelas menjamin adanya perlindungan terhadap budaya yang dihasilkan masyarakat. Sudah barang tentu harus diimplementasikan dengan baik dan benar. Maka dari itu hak-hak tradisional yang tertuang dalam bentuk-bentuk nyata dari ekspresi budaya tradisional harus dilindungi dengan baik oleh negara dan/atau secara khusus oleh masyarakat pengembannya, agar ekspresi budaya tradisional tidak punah dan disalahgunakan oleh pihak yang tidak bertanggung jawab atau bahkan penggunaan ekspresi budaya tradisional pada satu pihak yang memicu sengketa bisa dihindari. Seperti misalnya pada beberapa tahun yang lalu, telah terjadi permasalahan saling klaim budaya antar negara, mengenai klaim Malaysia terhadap produk budaya Indonesia diantaranya lagu Rasa Sayange, Reog Ponorogo, dan penggunaan Tari Pendet. Salah satu penyebabnya adalah karena belum jelasnya ketentuan yang mengatur perlindungan dan pelestarian produk budaya tradisional atau yang disebut dengan folklor. Belum jelasnya pengaturan perlindungan kesimpangsiuran pemahaman produk budaya tradisional dan proses pendaftaran hal cipta atas ekspresi budaya tradisional yang berbeda dengan pengaturan dalam sistem hak kekayaan intelektual $^{5}$ konvensional. Sehingga dalam melindungi ekspresi budaya tradisonal ini memerlukan tata kelola yang baik dalam sistem hukumnya. Sehingga dalam tulisan ini akan

4 Baca Pasal 18B ayat (2) Undang-Undang Negara Republik Indonesia Tahun 1945.

5 Suyud Margono, Hukum Hak Kekayaan Intelektual (HKI), Pustaka Reka Cipta, Bandung, 2015, Hlm. 1-2. 
dikaji bagaimana pengelolaan ekspresi budaya tradisional (EBT) di daerah pasca UndangUndang Nomor 28 Tahun 2014 tentang Hak Cipta (Perspektif Hukum Administrasi Negara)? Agar dengan tata kelola yang baik dalam administrasinya dapat lebih menjamin kepastian perlindungan hukum ekspresi budaya tradisional.

\section{B. PEMBAHASAN}

\section{Pengertin Ekspresi Budaya Tradisional (EBT)}

Ekspresi budaya tradisional adalah segala bentuk ekspresi, baik material (benda) maupun immaterial (tak benda), atau kombinasi keduanya yang menunjukkan keberadaan suatu budaya dan pengetahuan tradisional, yang bersifat turuntemurun. ${ }^{6}$ Dalam undang-undang sebelumnya yaitu Undang-Undang Nomor 19 Tahun 2002 tentang Hak Cipta yang sudah tidak berlaku lagi pada Bagian Ketiga Hak Cipta atas Ciptaan yang Penciptanya Tidak Diketahui Pasal 10 ayat (2) penyebutan ekspresi budaya tradisional dengan sebutan folklor. Folklor dalam Bukunya Purwadi yang berjudul "Folklor Jawa" memiliki definisi tradisi kolektif sebuah bangsa yang disebarkan dalam bentuk lisan maupun gerak isyarat, sehingga tetap berkesinambungan dari generasi ke generasi. ${ }^{7}$ Istilah folklore dimaksudkan untuk menyempitkan ruang lingkup suatu pengetahuan tradisional ke dalam ruang lingkup seni, sastra dan ilmu pengetahuan. ${ }^{8}$ Penyebutan lain atas folklore maupun pengetahuan tradisional adalah digolongkan sebagai intangible cultural heritage. $^{9}$

6 Pengertian tersebut diambil dari Rancangan UndangUndang tentang Pengetahuan Tradisional dan Ekspresi Budaya Tradisional.

7 Purwadi, Folklor Jawa, Pura Pustaka, Yogyakarta, 2009, Hlm. 1.

8 Arif Lutviansori, Hak Cipta dan Perlindungan Folklor di Indonesia, Graha Ilmu, Yogyakarta, 2010, Hlm. 2-3.

9 Intangible Cultural Heritage means the practices, representations, expressions, knowledge, skills - as well as the instruments, objects, artifacts and cultural spaces associated therewith - that communities, groups and, in some cases, individuals recognize as part of their cultural heritage. This intangible cultural heritage, transmitted from generation to generation, is constantly recreated by communities and groups in response to their
Hakikat folklor merupakan identitas lokal yang terdapat dalam kehidupan masyarakat tradisional. Rasa memiliki terhadap tradisi yang sudah mengakar dan menyerah menyebabkan emosi masing-masing warganya menjadi manunggal. ${ }^{10}$ Manfaat folklor sebagai monuman tradisi lisan, ternyata menunjukkan identitas cultural. Folklor menampilkan watak dan corak kebudayaan daerah. Historisitas daerah itu dimanivestasikan dan dengan demikian sekaligus juga karekter atau identitas. Dimensi historis cultural di wilayah tersebut diungkapkan, maka lewat folklore watak daerah itu tampil dengan jelas. ${ }^{11}$ Untuk itu ekspresi budaya tradisional yang dimiliki oleh bangsa Indonesia harus dilindungi dengan baik, agar karakteristik bangsa Indonesia yang banyak tertuang dalam budaya-budaya masing-masing daerah tidak pudar, bahkan tidak dimanfaatkan secara tidak bertanggung jawab.

\section{EBT merupakan asset bangsa}

Menurut Sanusi Bintang memberikan pengertian bahwa hak kekayaan intelektual adalah hak manual eksklusif yang terdiri dari dua macam hak, yaitu hak ekonomi (economic right) dan hak moral (moral right). ${ }^{12}$ Bila dilihat dalam Pasal 8 Undang-Undang Nomor 28 Tahun 2014, bahwa hak ekonomi merupakan hak eksklusif Pencipta atau Pemegang Hak Cipta untuk mendapatkan manfaat ekonomi atas suatu ciptaannya. Hak ekonomi yang dimaksudkan adalah mencakup penerbitan ciptaan, penggandaan ciptaan dalam segala bentuknya, penerjemahan, pengadaptasian,

environment, their interaction with nature and their history, and provides them with a sense of identity and continuity, thus promoting respect for cultural diversity and human creativity. For the purposes of this Convention, consideration will be given solely to such intangible cultural heritage as is compatible with existing international human rights instruments, as well as with the requirements of mutual respect among communities, groups and individuals, and of sustainable development. Lihat selengkapnya dalam https://en.wikipedia. org/wiki/Intangible cultural heritage, Intengible Cultural Heritage, diakses tanggal 26 Mei 2017.

10 Purwadi, Op.Cit., Hlm. 3.

11 Ibid., Hlm. 5.

12 Sudarmanto, KI dan HKI Serta Implementasinya Bagi Indonesia, PT Elex Media Komputindo, Jakarta, 2012, Hlm. 1. 
pengeransemenan, pentransformasian ciptaan, pendistribusian ciptaan atau salinannya, pertunjukan ciptaan, komunikasi ciptaan, dan penyewaan ciptaan. Selain itu, hak ekonomi sepertinya dijelaskan oleh Sudarmanto dalam bukunya "KI dan HKI serta Implementasinya bagi Indonesia" adalah hak yang dimiliki oleh seseorang Inventor dan pendesain untuk mendapatkan keuntungan atas invensi dan karya desain industrinya. Hak ekonomi tersebut berkembang dengan pemanfaatan hak secara komersial. Hal itu disebabkan karena untuk mewujudkan sebuah ide dan gagasan dalam sebuah tulisan, kemudian dilanjutkan dengan sebuah temuan produk dibidang teknologi (paten) maupun karya desain industri, tentunya memerlukan pengorbanan waktu, tenaga, dan biaya. Oleh karena itu, hasil suatu temuan karya intelektual harus dapat dikelola secara komersial, agar dapat mengembalikan modal dan memperoleh keuntungan. Berbeda dengan hak ekonomi, hak moral adalah hak yang melindungi kepentingan pribadi inventor (penemu) dan reputasi pendesain. Konsep ini adalah konsep yang berasal dari hukum continental yang berasal dari Prancis. Dalam konsep ini hak pencipta (droit auter, author rights), terbagi menjadi hak ekonomi untuk mendapatkan keuntungan yang bernilai ekonomi seperti uang, dan hak moral yang menyangkut perlindungan atas reputasi inventor dan pendesain. ${ }^{13}$ Pada prinsipnya sang pencipta dapat menggunakan hasil ciptaannya untuk apa saja seperti misalnya mengkomersialisasikan hasil ciptaannya untuk kepentingan dirinya maupun orang lain sesuai dengan aturan yang berlaku.

Banyak ahli setuju bahwa hukum HKI adalah sebuah bentuk kompensasi dan dorongan bagi orang untuk mencipta. Hal ini dapat menguntungkan bagi masyarakat dalam jangka panjang. ${ }^{14}$ Dalam hal ekspresi budaya tradisional menjadi bagian dari kekayaan intelektual yang dihasilkan oleh masyarakat dan diwariskan

13 Ibid., Hlm. 1-2.

14 Tim Lindsey, dkk., Hak Kekayaan Intelektual Suatu Pengantar, Alumni, Bandung, 2013, Hlm. 15. secara turun-temurun dan menjadi sebuah karakter bangsa sangat mendorong untuk dapat dimanfaatkan untuk memperoleh keuntungan bukan hanya moral akan tetapi ekonomi. Hak ekonomi inilah yang kadang diambil oleh pihak yang tidak seharusnya menggunakan produk ekspresi budaya tradisional tersebut. Seperti yang dicontohkan ekspresi budaya tradisional dapat menjadi pendorong sektor pariwisata. Dengan begitu maka produk ekspresi budaya tradisional akan dapat menghasilkan keuntungan secara ekonomis dalam jangka waktu lama dan terus menerus.

HKI adalah asset. ${ }^{15}$ Kekayaan intelektual merupakan asset bangsa yang tidak ternilai harganya. Dengan kekayaan intelektual yang diwujudkan dalam sebuah karya nyata akan dapat meningkatkan pembangunan suatu bangsa. Bangsa akan menjadi lebih maju bila digunakan untuk kemaslahatan masyarakat. Dalam hal ini bukan hanya kekayaan intelektual yang bersifat individual saja, akan tetapi juga yang bersifat komunal. Kekayaan Intelektual yang bersifat komunal, khususnya warisan budaya yang boleh disebut produk dari ekspresi budaya tradisional yang diwariskan secara turun-temurun. Produk ekspresi budaya tradisional juga dapat bernilai ekonomis. Hak ekonomis tersbeut dapat mensejahterakan masyarakat. Menurut Shahid Alikhan, penerapan sistem HKI merupakan batu loncatan dari sistem ekonomi modern di tingkat nasional dan sekaligus merupakan katalisator pembangunan. HKI merupakan asset untuk pertumbuhan ekonomi yang berbasis ilmu pengetahuan ${ }^{16}$ yang harus dikembangkan untuk meningkatkan kesejahteraan masyarakat bangsa Indonesia di era pasar global. Kemajuan pembangunan ekonomi suatu bangsa dapat diukur dari seberapa banyak kepemilikan HKInya. HKI merupakan fundamental perekonomian

15 Achmad Zen Umar Purba, Hukum Dalam Kolom, Tempo Publishing, Jakarta, 2016, Hlm.137 dikutip dari pembukuan perusahaan, HKI masuk di kolom asset. Dalam berbagai BIT, “investment”, termasuk IPR (HKI). Lihat antara lain IJEPA, Art. 58, f (6).

16 Ansori Sinungan, Perlindungan Desain Industri: Tantangan dan Hambatan dalam Praktiknya di Indonesia, Cetakan ke-1, Bandung: Alumni, 2011, Hlm. 148. 
suatu bangsa ${ }^{17}$ yang dapat digunakan untuk kepentingan masyarakat Indonesia. Selain itu HKI telah menjadi semacam alat efektif untuk membangun leverage dagang (trade leverage) dalam hubungan bilateral. ${ }^{18}$ Sehingga apabila HKI yang dimiliki suatu bangsa banyak maka dapat digunakan untuk memacu pertumbuhan ekonomi suatu bangsa untuk mensejahteraan rakyatnya.

\section{Pengaturan EBT belum tuntas}

Pengaturan EBT dalam Undang-Undang Nomor 28 Tahun 2014 tentang Hak Cipta memang belum sempurna. Dapat dilihat dari pengaturan EBT dalam undang-undang tersebut hanya ada di BAB V tentang Ekspresi Budaya Tradisional dan Ciptaan yang Dilindungi dan itupn hanya 2 (dua) pasal saja, yaitu Pasal 38 dan Pasal 39. Dalam pasal 38 ayat (1) tersebut diungkapkan bahwa hak cipta atas ekspresi budaya tradisional dipegang oleh negara. Diperjelas dalam ayat (2) nya bahwa negara wajib menginventarisasi, menjaga, dan memelihara ekspresi budaya tradisional. ${ }^{19}$ Sejauh

17 Andy Noorsaman Someng dalam presentasinya pada seminar Manfaat dan Strategi dalam Penggunaan Sistem Hak Kekayaan Intelektual oleh Dunia Usaha Termasuk Usaha Kecil dan Menengah pada tanggal 24 Juni 2008 di Jakarta dengan judul: Strategi Nasional dalam Pengembangan Sistem Hak Kekayaan Intelektual menyampaikan bahwa maksud utama dari Kebijakan Nasional Kekayaan Intelektual (KNKI) adalah menjadikan kekayaan intelektual sebagai sebuah mesin baru pertumbuhan (new engine of growth) di dalam meningkatkan kesejahteraan ekonomi dan sosial, dalam Ansori Sinungan, Perlindungan Desain Industri: Tantangan dan Hambatan dalam Praktiknya di Indonesia, Cetakan ke-1, , Bandung: Alumni, 2011, Hlm. 146.

18 Bambang Kesowo, Pengantar Umum Mengani Hak Atas Kekayaan Intelektual di Indonesia, Sekretariat Negara RI, Jakarta, hal. 3 dalam Henry Soelistyo, Hak Kekayaan Intelektual: Konsep, Opini, dan Aktualisasi, Buku Pertama, Penaku, Jakarta, 2014, HIm. 2.

19 Yang dimaksud dengan "ekspresi budaya tradisional" mencakup salah satu atau kombinasi bentuk ekspresi sebagai berikut
a. Verbal tekstual, baik lisan maupun tulisan, yang berbentuk prosa maupun puisi, dalam berbagai tema dan kandungan isi pesan, yang dapat berupa karya sastra ataupun narasi informative
b. Music, mencakup antara lain, vocal, instrumental, atau kombinasinya;
c. Gerak, mencakup antara lain, tarian;
d. Teater, mencakup antara lain, pertunjukan wayag

ini cukup jelas bahwa negara mempuyai tugas menginventarisasi, menjaga, dan memelihara ekspresi budaya tradisional. Tugas tersebut sampai saat ini masih kurang terperhatikan dan belum dilaksanakan dengan baik. Memang dalam pasal 38 ini bahwa ketentuan pemegang hak cipta atas EBT oleh negara dilaksanakan lebih lanjut akan diatur dengan Peraturan Pemerintah. Akan tetapi sampai saat ini belum ada Peraturan Pemerintah yang mengatur tentang EBT. Tentunya hal tersebut menjadi kendala dalam pelaksanaannya. Walaupun demikian bukan berarti perlindungan terhadap EBT tidak bisa dilakukan. Negara harus tetap mengusahakan aturan tersebut dalam dijalankan dengan memasukkan sedikit demi sedikit dalam program yang ada di setiap daerah. Amanah yang diemban negara sudah jelas diatur dalam konstitusi (dalam UUD Negara RI Tahun 1945). Gagasan negara hukum menuntut agar penyelenggaraan urusan kenegaraan dan pemerintahan harus didasarkan pada undang-undang dan memberikan jaminan terhadap hak-hak dasar rakyat. ${ }^{20}$

\section{Amanah bagi Negara dalam melindungi EBT}

Pembukaan Undang-Undang Dasar Negara Republik Indonesia Tahun 1945 Alenia ke-4 yang berbunyi:

"Kemudian daripada itu untuk membentuk suatu Pemerintahan Negara Indonesia yang melindungi segenap bangsa Indonesia dan seluruh tumpah darah Indonesia dan untuk memajukan kesejahteraan umum, mencerdaskan kehidupan bangsa, dan ikut melaksanakan ketertiban dunia yang berdasarkan

dan sandiwara rakyat;

e. Seni rupa, baik dalam bantuk dua dimensi maupun tiga dimensi yang terbuat dari berbagai macam bahan seperti kulit, kayu, bamboo, logam, batu, keramik, kertas, tekstil, dan lain-lain atau kombinasinya; dan

f. Upacara adat.

Lebih jelasnya lihat Penjelasan Undang-Undang Nomor 28 Tahun 2014 tentang Hak Cipta.

20 Ridwan HR, Hukum Administrasi Negara, PT RajaGrafindo Persada, Jakarta, 2014, Hlm. 94. 
kemerdekaan, perdamaian abadi dan keadilan sosial, ......"

Perlindungan bagi segenap bangsa Indonesia dan seluruh tumpah darah Indonesia meliputi sumber daya manusia dan sumber daya alam di wilayah NKRI yang menjadi tujuan mulia dalam pengelolaan suatu bangsa. Perlindungan yang diberikan seharusnya mencapai pada sebuah keadaan yang mensejahterakan masyarakat. Kesejahteraan umum yang juga menjadi salah satu tujuan nasional bangsa Indonesia yang harus terus diupayakan oleh pemerintah melalui berbagai sumber daya yang ada termasuk melindungi budaya (tradisional) yang dihasilkan dari berbagai suku bangsa yang ada di Indonesia. Budaya yang dilindungi oleh negara harus mengarah pada kondisi yang dapat mensejahterakan masyarakat Indonesia. Artinya dengan melindungi EBT dapat membuat masyarakat lebih sejahtera.

Berbagai produk ekspresi budaya tradisional yang dihasilkan oleh bangsa Indonesia menjadi sebuah asset yang sangat berharga sekaligus menunjukkan bahwa bangsa Indonesia mempunyai karakter yang khas yang membedakan dari Negara-negara lain. Bangsa Indonesia kaya akan budaya dan budaya tersebut haruslah terus diupayakan perlindungannya oleh Negara dan masyarakat Indonesia. Upaya mewujudkan perlindungan untuk kesejahteraan umum dalam bidang budaya tersebut antara lain tertuang dalam Pasal 18B ayat (2) Undang-Undang Dasar Negara Republik Indonesia Tahun 1945 yang berbunyi, "Negara mengakui dan menghormati kesatuankesatuan masyarakat hukum adat beserta hakhak tradisionalnya sepanjang masih hidup dan sesuai dengan perkembangan masyarakat dan prinsip Negara Kesatuan Republik Indonesia...”. Ketentuan konstitusi ini merupakan politik hukum (legal politic) yang menunjukkan bahwa terdapat prinsip-prinsip dan arah pembangunan nasional dalam tata kelola budaya bangsa Indonesia. Arah kebijakan dan penetapan aturan yang menyangkut kepentingan suatu bangsa harus ditentukan dengan jelas secara konstitusi dan pengaturan lebih lanjut dalam peraturan yang berada di bawahnya.

Peran serta masyarakat juga sangat menentukandalampembentukanhukum. Hakmasyarakat tersebut telah dijamin secara konstitusional dalam Pasal 28 Undang-Undang Dasar Negara Republik Indonesia Tahun 1945 (UUD NRI Tahun 1945) yang berbunyi, "Kemerdekaan berserikat dan berkumpul, mengeluarkan pikiran dengan lisan dan tulisan dan sebagainya ditetapkan dengan undang-undang". Itu artinya bahwa masyarakat dapat berperan aktif menyampaikan pikirannya dalam rangka membangun bangsanya sesuai kemampuannya. Hal itu juga diperkuat secara konstitusional salah satunya pada Pasal 28C ayat (1) UUD NRI Tahun 1945 yang menyatakan bahwa, "Setiap orang berhak mengembangkan diri melalui pemenuhan kebutuhan dasarnya, berhak mendapatkan pendidikan dan memperoleh manfaat dari ilmu pengetahuan dan teknologi, seni dan budaya, demi meningkatkan kualitas hidupnya dan demi kesejahteraan umat manusia".

Salah satu yang dijelaskan dalam Pasal 28C ayat (1) UUD NRI Tahun 1945 mengungkapkan bahwa setiap orang atau seluruh masyarakat berhak mendapatkan pendidikan dan memperoleh manfaat dari sebuah budaya demi meningkatkan kualitas hidupnya dan demi kesejahteraan umat manusia. Dalam hal ini masyarakat berhak ikut serta dalam melindungi budaya bangsa Indonesia yang sangat beragam dan banyak. Ekspresi budaya tradisional di Indonesia yang kepemilikannya secara komunal dalam perlindungannya harus melibatkan peran serta masyarakat. Jean Jacques Rousseau dalam bukunya yang berjudul "Du Contract Social" dalam teorinya mengenai perjanjian masyarakat mengungkapkan bahwa dalam suatu negara, natural liberty telah berubah menjadi civil liberty dimana rakyat memiliki hakhaknya. ${ }^{21}$ Menurut Rousseau, sejauh kehendak manusia diarahkan pada kepentingan sendiri atau kelompoknya maka kehendak mereka tidak bersatu atau bahkan berlawanan, tetapi sejauh diarahkan pada kepentingan umum bersama sebagai suatu bangsa, semua kehendak itu bersatu

21 Bahder Johan Nasution, Negara Hukum dan Hak Asasi Manusia, Mandar Maju, Bandung, 2012, Hlm. 55. 
menjadi satu kehendak, yaitu kehendak umum atau yang dikenal dengan istilah volte general. ${ }^{22}$ Kehendak rakyat Indonesia dalam menjaga ekspresi budaya tradisional perlu dipahami oleh pemeritah, terutama parlemen (lembaga legislatif), untuk dapat mewujudkan keinginan masyarakat sehingga tidak atas kehendak negara saja (pemerintah) secara sepihak.

Perwujudan peran serta masyarakat tertuang dalam Teori Kedaulatan Rakyat. Teori kedaulatan rakyat adalah suatu cara atau sistem yang menentukan bagaimana memecahkan sesuatu soal yang terjadi dalam masyarakat untuk memenuhi kehendak umum. ${ }^{23}$ Pemenuhan kehendak umum juga telah tertuang dalam ideologi bangsa Indonesia yaitu Pancasila. Pancasila adalah dasar negara yang menjadi dasar penyelenggaraan hidup berbangsa dan bernegara, termasuk sebagai dasar dalam penyelenggaraan segala ketentuan peraturan perundang-undangan Republik Indonesia. Dalam sila keempat Pancasila disebutkan bahwa "Kerakyatan yang dipimpin oleh hikmat kebijaksanaan dalam permusyawaratan/perwakilan." Ungkapan tersebut berarti rakyat dalam menjalankan kekuasaannya melalui sistem perwakilan, dan keputusan-keputusannya diambil dengan jalan musyawarah, yang dipimpin oleh pikiran yang sehat serta penuh tanggung jawab, baik kepada Tuhan Yang Maha Esa maupun kepada rakyat yang diwakilinya. ${ }^{24}$ Teori kedaulatan rakyat yang dipahami oleh Immanuel Kant yang menyatakan bahwa pemerintahan konstitusional yang sebagai penegak hukum tertinggi (Constitutional government as enforcement of the Higher Law), karena tujuan negara adalah untuk menegakkan hukum dan menjamin kebebasan dari warganya, yaitu kebebasan dalam batas-batas perundangundangan. Sedangkan yang berhak membuat undang-undang adalah rakyat itu sendiri. ${ }^{25}$

Pada abad ke-18 Jen Jacques Rousseau mengemukakan bahwa dasar terjadinya suatu Negara adalah 'perjanjian masyarakat' (Contrat 22 Ibid.

23 Suyud Margono, Hukum..Op.Cit., Hlm. 27.

24 Bahder Johan Nasution, Negara..., Op.Cit., Hlm. 60.

25 Suyud Margono, Hukum..., Op.Cit., Hlm. 27-28.
Social) yang diadakan oleh dan antara anggota masyarakat untuk mendirikan suatu negara. Teori JJ Rousseau yang menjadi dasar paham 'Kedaulatan Rakyat' mengajarkan bahwa Negara bersandar atas kemauan rakyat, demikian pula halnya semua peraturan-perundangan adalah penjelmaan kemauan rakyat tersebut. ${ }^{26}$

Peran serta masyarakat dapat dilakukan secara langsung maupun tidak langsung. Secara tidak langsung, masyarakat dapat menyampaikan aspirasinya melalui wakilnya yang berada di lembaga legislatif. Peran lembaga legislatif yang dalam hal ini disebut negara, tertuang dalam teori kedaulatan negara. Teori Kedaulatan Negara (Staats-souvereiniteit) yang dikemukakan oleh Jean Bodin dan George Jelinek dalam kerangka melindungi kekayaan masyarakat tradisi. Menurut teori kedaulatan negara: "Kekuasaan tertinggi ada pada negara dan negara mengatur kehidupan anggota masyarakatnya. Negara yang berdaulat melindungi anggota masyarakatnya terutama anggota masyarakat yang lemah". ${ }^{27}$ Suyud Margono dalam bukunya berjudul "Hukum Hak Kekayaan Intelektual (HKI)" menyatakan bahwa teori kedaulatan negara, teori kedaulatan hukum dan teori kedaulatan rakyat pada dasarnya mengakui, bahwa rakyat telah mendelegasikan kedaulatannya kepada negara melalui organorgannya. $^{28}$ Seperti yang dijelaskan oleh Rousseau bahwa hukum tiada lain merupakan perwujudan dari "The general will" (kehendak rakyat ${ }^{29}$, kehendak rakyat yang diwujudkan melalui sebuah pendelegasian kedaulatannya pada sebuah organ negara yang saat ini berupa parlemen (lembaga legislatif). Kehendak rakyat dalam melindungi ekspresi budaya tradisional dalam sistem Hak Kekayaan Intelektual harus

26 Samidjo dan A. Sahal, Tanya Jawab Pengantar Ilmu Hukum, h. 46 dalam Titik Triwulan Tutik, Pengantar Ilmu Hukum, Prestasi Pustakaraya, 2006, Hlm. 151.

27 Jimly Asshiddiqie, Gagasan Kedaulatan Rakyat dalam Konstitusi dan Pelaksanaannya di Indonesia, PT Ichtiar Baru van Hoeve, Jakarta, 1994, Hlm. 121, dalam Suyud Margono, Hukum Hak Kekayaan Intelektual (HKI), Pustaka Reka Cipta, Bandung, 2015, Hlm. 2223.

28 Suyud Margono, Hukum..., Op.Cit., Hlm. 28.

29 Bahder Johan Nasution, Negara..., Op.Cit., Hlm. 71. 
diwujudkan dalam sebuah Undang-Undang yang sesuai dengan kehendak rakyat. UndangUndang yang bisa memberikan hak-hak dalam melindungi kepentingan masyarakat pengemban maupun masyarakat yang mempunyai keinginan mengembangkan budaya atau tradisi atas budaya tradisional yang dimiliki bangsa Indonesia untuk mencapai kesejahteraan.

Menurut teori yang dikemukakan oleh JJ Rousseau bahwa kemauan orang seluruhnya yang telah mereka serahkan kepada suatu organisasi (yaitu Negara) yang telah terlebih dahulu mereka bentuk dan diberi tugas membentuk hukum yang berlaku dalam masyarakat. ${ }^{30}$ Seperti yang diungkapkan oleh Immanuel Kant bahwa pemerintahan konstitusional yang sebagai penegak hukum tertinggi serta Jean Bodin dan George Jelinek juga megungkapkan bahwa kekuasaan tertinggi ada pada negara dan negara mengatur kehidupan anggota masyarakatnya ${ }^{31}$, mengamanatkan bahwa negara sebagai wakil rakyat dan penegak hukum tertinggi. Negara adalah sebuah sistem hukum. ${ }^{32}$ Sehingga negara wajib melindungi budaya khususnya EBT seperti yang tertuang dalam Pasal 38 ayat (1) UndangUndang Nomor 28 Tahun 2014 tentang Hak Cipta yang saat ini masih belum jelas pengelolaan maupun perlindungannya.

\section{Pengelolaan EBT di daerah}

Produk ekspresi budaya tradisional yang dimiliki oleh masyarakat dalam lingkup kekayaan intelektual termasuk dalam hak komunal. Hak komunal merupakan sumber inspirasi penting dalam pengembangan inovasi modern, karena itu keberadaannya perlu mendapatkan pengakuan dan perlindungan secara layak dalam tatanan hukum baik secara lokal, regional maupun internasional. Pengembangan inovasi baru berdasarkan hak komunal merupakan hal yang sangat penting dilakukan oleh komunitas lokal pemiliknya sendiri, supaya nilai tambah yang diperoleh sepenuhnya

30 CST Kansil, Pengantar Ilmu Hukum dan Tata Hukum Indonesia, h. 59 dalam Titik Triwulan Tutik, Pengantar Ilmu Hukum, Prestasi Pustakaraya, 2006, Hlm. 151.

31 Jimly Asshiddiqie, Gagasan..., Loc.Cit, Hlm. 121.

32 Hlm. 148. dapat dinikmati oleh mereka. ${ }^{33}$

Pengelolaan EBT dapat dilakukan dengan mendokumentasikan setiap hak komunal yang termasuk dalam EBT yang dimiliki daerah, dengan tujuan: ${ }^{34}$

a. Mengklaim jenis-jenis hak komunal milik daerah.

b. Menangkal pendaftaran hak komunal yang dilakukan pihak asing.

c. Menyebarluaskan kemanfaatan hak komunal kepada masyarakat Indonesia.

Langkah awal yang dapat dilakukan dalam pengelolaan EBT di daerah adalah dengan melakukan identifikasi terhadap seluruh produk EBT milik daerah yang ada di seluruh Indonesia. Identifikasi dapat dilakukan dengan menginventarisasi segala produk EBT di daerah masing-masing. Dalam melakukan inventarisasi produk EBT dapat dilakukan dengan pemberdayaan dan optimalisasi keberadaan Unit Pengelola Kekayaan Intelektual (UPKI) di setiap daerah melalui Sentra HKI dan/ atau Klinik HKI untuk pengelolaannya sesuai yang diamanahkan dalam Undang-Undang Nomor 18 Tahun 2002 tetang Sistem Nasional Penelitian, Pengembangan, dan Penerapan Ilmu Pengetahuan dan Teknologi ${ }^{35}$ dan dengan berkoordinasi dengan pihak Kementerian Hukum dan HAM dan juga Pemerintah Daerah setempat. Pertumbuhan Sentra HKI disetiap daerah harus didorong yang pembentukannya dipelopori melalui perguruan tinggi-perguruan tinggi yang ada didaerah setempat di seluruh Indonesia. Selanjutnya apabila sudah dilakukan identifikasi dan inventarisasi, maka dapat dilakukan upaya perlindungan melalui cara-cara yang sudah tertera dalam peraturan perundang-undangan yang berlaku. Misalnya seperti yang tertera dalam Pasal 39 Undang-Undang Hak Cipta bahwa untuk produk EBT yang tidak diketahui penciptanya dan ciptaan tersbeut belum dilakukan pengumuman, maka negar dapat memegang hak ciptanya dan melakukan pengumuman demi

33 Sudarmanto, Op.Cit., Hlm. 111.

34 Ibid., Hlm. 113.

35 Ibid., Hlm. 115. 
kepentingan si penciptanya atau kepentingan komunal masyarakat adat atau pengembannya. Hal tersebut dapat dilakukan oleh Pemerintah Daerah setempat dengan mengkoordinasikannya dengan Pemerintah Daerah yang lain agar tidak terjadi saling klain atas produk EBT tersebut dengan jalan musyawarah.

Peran Pemerintah Daerah atas pengelolaan EBT dapat melalui Dinas Pariwisata yang dimilikinya dalam melakukan inventarisasi EBT dengan bekerjasama dengan stakeholder dan Sentra HKI yang ada. Dalam melaksanakan pengelolaan EBT, pemerintah harus menerapkan asas-asas umum pemerintahan yang baik. Asas tersebut menjadi landasan dalam pengelolaan EBT agar dalam jangka pendek maupun jangka penjang, EBT dapat terinventaris (teridentifikasi) dan terkelola dengan baik, sehingga adanya perlindungan dengan tata kelola EBT yang baik yang akhirnya akan terwujud kesejahteraan bagi masyarakat luas. Dalam pengelolaan EBT dapat dilihat dari perpektif hukum administrasi negara melalui penerapan beberapa asas umum penyelenggaraan negara ${ }^{36}$ yang baik.

Pertama, Asas Kepastian Hukum, yaitu asas dalam negara hukum yang mengutamakan landasan peraturan perundang-undangan, kepatutan, dan keadailan dalam setiap kebijakan penyelenggara negara. Dalam pengelolaan EBT pemerintah harus berlandaskan aturan hukum yang jelas. Seperti yang tertuang dalam UndangUndang Hak Cipta bahwa hak cipta atas EBT dipegang oleh negara. Perlu adanya pembuatan Peraturan pemerintah yang disegerakan agar dapat menjadi landasan dalam melaksanakan tugas bagi pemerintah daerah. Walaupun belum adanya Peraturan Pemerintah yang mengatur EBT sebenarnya pemerintah daerah dapat juga melakukan pengelolaan EBT seperti yang dicontohkan dalam sebuah penelitian terhadap Tarian Tradisional dan Kerajinan Tangan yang ada di Provinsi Kepulauan Bangka Belitung. Pemerintah Daerah telah melakukan perlindungan dan inventarisasi terhadap Tarian Tradisional dan Kerajinan Tangan, walaupun belum optimal dengan berbagai kendalanya. Seharusnya pemerintah daerah membuat kebijakan melalui program kerjanya untuk melindungi EBT yang ada.

Kedua, Asas Tertib Penyelenggaraan Negara, yaitu asas yang menjadi landasan keteraturan, keserasian, dan keseimbangan dalam pengendalian penyelenggaraan negara. Dalam pengelolaan EBT harus adanya keteraturan, keserasian dan keseimbangan dalam pelaksanaannya. Keteraturan ditandai dengan adanya peraturan perundang-undangan yang lengkap dan jelas, serta adanya sistem tata kelola yang baik, akuntabel dan transparan mulai dari pusat sampai daerah. Sehingga sistem tata kelola EBT yang baik dengan didukung dengan landasan hukum yang kuat, serta sumberdaya yang memadai dan profesinal maka akan terwujudnya kesejahteraan bagi masyarakat. Keseimbangan dalam proses pendanaan antar daerah dalam pengelolaan EBT juga menjadi hal penting, sehingga membutuhkan prinsip keadilan dalam pendanaannya. Karena antara satu daerah dengan daerah yang lain berbeda kebutuhannya dan perlu adanya program yang jelas disetiap daerahnya untuk mendapatkan pendanaannya.

Ketiga, Asas Kepentingan Umum, yaitu asas yang mendahulukan kesejahteraan umum dengan cara aspiratif, akomodatif, dan selektif. Asas ini mengajarkan bahwa dalam pengelolaan EBT harus melibatkan aspirasi dari masyarakat, disesuaikan dengan kepentingan masyarakat dan selektif dalam pengambilan aspirasinya. Sehingga pengelolaan EBT juga dapat melibatkan masyarakat daerah yang memiliki kepedulian akan produk-produk EBT yang dihasilkan oleh masyarakat setempat. Hasil dari kebijakan pemerintah atas pengelolaan EBT dapat diterima oleh masyarakat dan dapat mensejahterakan masyarakat. Jadi kepentingan umum harus didahulukan dengan melibatkan masyarakat dalam proses pembuatan kebijakan pengelolaan EBT seperti yang tertuang dalam berbagai peraturan perundang-undangan yang mengamanatkan harus adanya keterlibatan atau 
peran aktif masyarakat atau stakeholder dalam setiap pembuatan kebijakan.

Keempat, Asas keterbukaan, yaitu asas yang membuka diri terhadap hak masyarakat untuk memperoleh informasi yang benar, jujur, dan tidak diskriminatif tentang penyelenggaraan negara dengan tetap memerhatikan perlindugan atas hak asasi pribadi, golongan, dan rahasia negara. Dalam pengelolaan EBT harus adanya sikap terbuka bagi pemerintah. Keterbukaan dalam memberikan informasi yang bermanfaat bagi pengelolaan EBT disuatu daerah agar EBT dapat dilestarikan, dimanfaatkan, dan dilindungi dengan baik. Pemerintah juga harus memberikan informasi mengenai pentingnya perlindungan EBT kepada masyarakat luas terutama masyarakat adat atau masyarakat pengembannya. Sehingga masyarakat adat atau masyarakat pengembannya menjadi sadar akan hukum yang ada untuk dapat diajak kerjasama dalam melindungi EBT tersebut. Penyampaian informasi harus disampaikan secara terus menerus dan dibina, misalnya melalui sosialisasi dan kegiatan pembinaan terhadap pengembangan dan pelestarian produk EBT serta perlindungnnya dengan memberikan bantuan materiil maupun non materiil dari pemerintah.

Kelima, Asas Proporsionalitas, yaitu asas yang mengutamakan keseimbangan antara hak dan kewajiban penyelenggaran negara. Asas ini dapat mendorong kinerja pemerintah dalam penjagaan EBT. Kewajiban pemerintah sudah jelas tertuang dalam undang-undang hak cipta bahwa negara memegang hak cipta atas EBT. Sehingga negara berkewajiban membuat program kedepan untuk melakukan pengelolaan dan penjagaan EBT agar tidak dimanfaatkan oleh pihak yang tidak bertanggung jawab atau tidak memiliki izin untuk kepentingan ekonomis. Negara juga berkewajiban membuat regulasi yang baik dan lengkap agar perlindungan EBT dapat dilakukan dengan berlandasakan aturanaturan yang kuat dan lengkap. Karena saat ini perlindungan EBT masih terhambat oleh belum lengkapnya aturan yang ada, ataupun belum ada peraturan yang lebih khusus dalam bidang kekayaan intelektual yang mengaturnya.
Keenam, Asas Profesionalitas, yaitu asas yang mengutamakan keahlian yang berlandaskan kode etik da ketentuan peraturan perundangundangan yang berlaku. Dalam melindungi EBT di dalam pemerintahan perlu adanya Sumber Daya Manusia yang mumpuni di bidang kekayaan intelektual. Untuk itu perlu tenaga professional untuk menangani hal ini. Pemerintah daerah dapat mengajak Perguruan Tinggi dan stakeholder yang peduli dengan EBT. Sehingga dalam pengelolaan produk EBT melibatkan sumber daya yang professional dan ahli dalam bidangnya.

Ketujuh, Asas Akuntabilitas, yaitu asas yang menentukan bahwa setiap kegiatan dan hasil akhir dari kegiatan penyelenggaraan negara harus dapat dipertanggungjawabkan kepada masyarakat atau rakyat sebagai pemegang kedaulatan tertinggi negara sesuai dengan ketentuan peraturan perundang-undanagn yang berlaku. Akhirnya, pengelolaan produk-produk hasil EBT harus dapat dipertanggungjawabkan kepada masyarakat Indonesia terutama masyarakat adat atau masyarakat pengembannya dengan capaian adalahkesejahteraanmasyarakatluas.Pengelolaan produk EBT akan dapat dipertanggungjawabkan apabila dalam pengelolaannya sesuai dengan peraturan yang berlaku dan mempunyai dasar hukum yang kuat dan jelas serta transparan, melalui sistem tata kelola yang baik.

\section{SIMPULAN}

Pengelolaan terhadap EBT menjadi suatu keharusan bagi Bangsa Indonesia. Sebab saat ini Indonesia telah masuk pada era pasar bebas yang suatu saat dapat mengerus kebudayaan yang menjadi cirri khas Bangsa Indonesia. Produk EBT dapat dikomersialisasikan dan dikapitalisasi oleh pihak yang tidak bertanggung jawab demi kepentingan dirinya sendiri. Untuk itu perlu adanya pengelolaanya yang baik dengan cara menyusun peraturan perundang-undangan yang lebih lengkap, adanya peran serta pemerintah daerah, stakeholder dan perguruan tinggi yang memiliki Sentra HKI dalam pengelolaan produkproduk EBT dengan cara mengidentifikasi dan 
menginventarisasikannya yang selanjutnya diberikan perlindungan sesuai dengan peraturan perundang-undangan yang berlaku, serta dilakukan pengembangan, pemanfaatan, promosi, dan pelestarian terhadap produk-produk EBT disetiap daerah dengan memperhatikan dan melaksanakan asas-asas umum pemerintahan yang baik dalam pengelolaannya agar terwujudnya tujuan negara Indonesia yaitu kesejahteran umum bagi seluruh rakyatnya.

\section{DAFTAR PUSTAKA}

Buku

Asshiddiqie, Jimly. 1994. Gagasan Kedaulatan Rakyat dalam Konstitusi dan Pelaksanaannya di Indonesia, PT Ichtiar Baru van Hoeve: Jakarta.

HR, Ridwan. 2014. Hukum Administrasi Negara, PT RajaGrafindo Persada: Jakarta.

Johan Nasution, Bahder. 2012. Negara Hukum dan Hak Asasi Manusia. Mandar Maju: Bandung.

Lindsey, Tim, dkk. 2013. Hak Kekayaan Intelektual Suatu Pengantar. Alumni: Bandung.

Lutviansori, Arif. 2010. Hak Cipta dan Perlindungan Folklor di Indonesia. Graha Ilmu: Yogyakarta.

Margono, Suyud. 2015. Hukum Hak Kekayaan Intelektual (HKI). Pustaka Reka Cipta: Bandung.

Purwadi. 2009. Folklor Jawa. Pura Pustaka: Yogyakarta.

Sinungan, Ansori. 2011. Perlindungan Desain Industri: Tantangan dan Hambatan dalam Praktiknya di Indonesia. Alumni: Bandung.

Soelistyo, Henry. 2014. Hak Kekayaan
Intelektual: Konsep, Opini, dan Aktualisasi. Penaku: Jakarta.

Sudarmanto. 2012. KI dan HKI Serta Implementasinya Bagi Indonesia, PT Elex Media Komputindo: Jakarta.

Triwulan Tutik, Titik. 2006. Pengantar Ilmu Hukum. Prestasi Pustakaraya: -

Zen Umar Purba, Achmad. 2016. Hukum Dalam Kolom. Tempo Publishing: Jakarta.

\section{Peraturan Perundang-undangan}

Undang-Undang Negara Republik Indonesia Tahun 1945.

Undang-Undang Nomor 28 Tahun 2014 tentang Hak Cipta.

Rancangan Undang-Undang tentang Pengetahuan Tradisional dan Ekspresi Budaya Tradisional.

\section{Website}

https://en.wikipedia.org/wiki/Intangible cultural_heritage, Intengible Cultural Heritage, diakses tanggal 26 Mei 2017.

Indonesia's Population: Ethnicity and Religion in a Changing Political Landscape. Institute of Southeast Asian Studies. 2003 dalam Suku Bangsa di Indonesia, https:// id.wikipedia.org/wiki/Suku bangsa_di Indonesia\#Referensi, diakses tanggal 26 Mei 2017.

Suku Bangsa di Indonesia, https:// id.wikipedia.org/wiki/Suku bangsa di Indonesia\#Referensi, diakses tanggal 26 Mei 2017.

\section{Lain-lain}

Andy Noorsaman Someng dalam presentasinya 
pada seminar Manfaat dan Strategi dalam Penggunaan Sistem Hak Kekayaan Intelektual oleh Dunia Usaha Termasuk Usaha Kecil dan Menengah pada tanggal 24 Juni 2008 di Jakarta dengan judul: Strategi Nasional dalam Pengembangan Sistem Hak Kekayaan Intelektual.

\section{Biodata Penulis}

Data Pribadi

- Nama Lengkap

: Sigit Nugroho

- Nama Panggilan

: Sigit

- Tempat, Tanggal Lahir

: Purworejo, 10 Februari 1984

- Umur

: 33 tahun

- Alamat

: Perum Indo Residence Jl. Singkur No. 30, RT. 006 RW. 002 Selindung, Gabek, Pengkalpinang.

- Pekerjaan : Dosen FH UBB

- Nomor HP : 085225314318

- e-mail

- Agama : c_git_tik@yahoo.com/snugroho571@gmail.com

- Jenis Kelamin : Islam

- Kewarganegaraan

: Laki-laki

: Indonesia

\section{Pangkat dan Golongan}

- Golongan/Pangkat : Illb/Penata Muda Tk. I

- Jenjang Jabatan Akademik : : Asisten Ahli (AA)

- NIP

: 198402102012121005

- NIDN

: 0210028401 